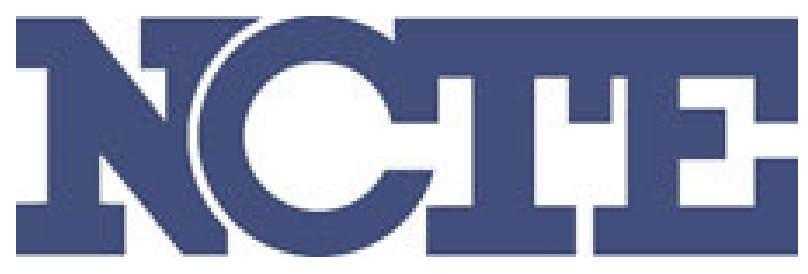

Survey Courses, Indian Literature, and the Way to Rainy Mountain Author(s): Kenneth M. Roemer

Reviewed work(s):

Source: College English, Vol. 37, No. 6 (Feb., 1976), pp. 619-624

Published by: National Council of Teachers of English

Stable URL: http://www.jstor.org/stable/376157

Accessed: 02/01/2012 18:24

Your use of the JSTOR archive indicates your acceptance of the Terms \& Conditions of Use, available at http://www.jstor.org/page/info/about/policies/terms.jsp

JSTOR is a not-for-profit service that helps scholars, researchers, and students discover, use, and build upon a wide range of content in a trusted digital archive. We use information technology and tools to increase productivity and facilitate new forms of scholarship. For more information about JSTOR, please contact support@jstor.org. 


\section{Survey Courses, Indian Literature, and The Way to Rainy Mountain}

Teaching Native American literature to non-Indian students involves as much unlearning as learning. Before students can even begin to appreciate the diversity of the many different Indian cultures and the richness of traditional oral or modern written Indian literature, they have to reevaluate old stereotypes and beware of new ones: misconceptions such as the Plains Warrior as Universal Indian, Indians as kid stuff, and Indians as "vanishing relics" of "dead" cultures; and new stereotypes such as the Indian as ecological Saint, Patriot Chief, or the counter image to the wooden Indian-the assumption that every Indian breast houses an epic poem.

These and other related problems have attracted quite a bit of attention during the last few years-convention seminars, new anthologies, and bibliographic resumés of Indian studies attest to that. But panelists, editors, and scholars of ten assume that an instructor will be offered the luxury of an entire course on Indians or at least enough time to survey a 300-page anthology. In reality most high school and college teachers only have a limited time to discuss Indians, possibly as part of a "minorities" section in an introduction to American literature. The teacher thus faces a very difficult question: how do you introduce over a millennium of diversified Indian literatures with one short, "representative" book? Given this ridiculous situation, one option (there are really no solutions) is to assign The Way to Rainy Mountain (1969), a lyric combination of Kiowa legends, historical and anthropological fact, and personal reminiscence written by N. Scott Momaday, the Pulitzer Prize winning author of House Made of Dawn (1968).

Of course there are bound to be disadvantages to using one book. The Way to Rainy Mountain focuses on only one tribe, at one time the lifestyle of that tribe resembled the stereotyped lifestyle of the Plains Warrior, and N. Scott Momaday is certainly not a "typical" Indian. But handled correctly, these apparent disadvantages can be advantages in the classroom. Because Momaday limits himself to his own tribe, he has the time to provide the cultural and historical background

Kenneth M. Roemer is Managing Editor of American Literary Realism, Assistant Dean of the Graduate School, and an Associate Professor at the University of Texas at Arlington. He is the autbor of The Obsolete Necessity: America in Utopian Writings, 1888-1900.

This article is a condensed version of "Teaching Indianness: The Way to Rainy Mountain," a paper presented at the Seventeenth Annual Meeting of the Western Social Science Convention, Denver, on May 2, 1975. The paper included bibliograpbic surveys of recent antbologies and studies of The Way to Rainy Mountain. 
material that nonIndian students need before they can appreciate how the land, legends, and ceremonies functioned and still function in past and present Indian cultures. True, the "golden era" (1740-1833) of the Kiowa recalls the Plains Warrior and Patriot Chief stereotypes, but Momaday's subtle use of these images undercuts their one-dimensional nature. As Vine Deloria argues in Custer Died for Your Sins (1969), many nonIndians feel cheated if they are not treated to the conventional image of a feathered brave bestriding a charging steed. Certainly the dramatic life of the raiding, buffalo-hunting, sun-worshipping Kiowa of the golden era should fulfill this expectation and convince students that Momaday's Indians are "real" Indians. But Momaday places this reality within the context of several other ancient and modern Kiowa realities: the religion-science of traditional myths, the collapse of the Plains culture, family history, childhood memories, and the mature reflections of an educated, urban Indian. The one-dimensional Plains stereotype crumbles after such a reading experience. Finally, Momaday's diversified background and his many achievements-his reservation and urban experiences, his memberships in the Kiowa Gourd Dance Society and academic associations, his $\mathrm{Ph}$. D., his roles as poet, novelist, essayist, critic, lecturer, professor, and Pulitzer Prize winner-make him a rather "unrepresentative" Indian. Occasionally panelists at conventions even suggest that he is not a "real" Indian; instead he is an outsider who can't understand the "average" Indian experience. There may be some truth to this argument. Still it would be foolish to exaggerate it, since Momaday's life can be used to convince non-Indian students that modern Indians are not all pathetic creatures "caught between two worlds." Momaday's life proves that Indians can be enriched by both worlds.

Thus the apparent weaknesses of The Way to Rainy Mountain-the focus on one tribe, the Plains image, and an atypical author-can become strengths in the classroom. There are also obvious practical advantages to using this book as an introduction to Indian literature. It's short ( 89 pages in cloth; 119 pages in paper; both with wide margins); it's easy to read (many students have difficulty with House Made of Dawn); and it's available in an inexpensive paperback edition (Ballantine, \$1.25). Another practical characteristic is that in spite of its brevity, The Way to Rainy Mountain offers examples of every major traditional and modern form of Indian literature. There are descriptions of ceremonies and sacred objects (the Sun Dance, the Tai-me, and the Ten Grandmothers), ancient myths and songs; and Momaday's father's striking traditional illustrations suggest the importance of the visual arts in Kiowa culture. Momaday also uses vignettes that reveal the traditional concept of the power of the word (VIII,XIV), and his own style demonstrates the traditional technique of repeating key words (XXIV). During the nineteenth and early twentieth centuries when these ancient forms of expression were declining, Indian speeches and autobiographies began to attract attention. Occasionally Momaday includes bits of speeches (III), and almost a third of the book is autobiographical. Finally, The Way to Rainy Mountain offers some excellent examples of modern Indian essays, fiction, and poetry. Yvor Winters described the introductory essay as "one of the greatest pieces of short prose I have ever read." Momaday's adaptations of myths and his autobiographical

1 "Rainy Mountain," The Reporter, 23 Feb. 1967, p. 8. 
vignettes are characterized by a striking economy and the ability to convey "intensely felt" "perceptions that resist formulation. . .just beyond the ends of the nerves." ${ }^{2}$ The poems that frame the book demonstrate Momaday's ability to emulate the powerful simplicity of Kiowa imagery ("Headwaters") and a dense Faulknerian style rich with the ironies of the vitality rooted in the cold, final world of an Indian grave ("Rainy Mountain Cemetery").

The variety of traditional and modern styles woven throughout The Way to Rainy Mountain makes it a fascinating survey of Indian literature. But this prose poem is much more than a creative anthology. The fundamental appeal of $T$ he Way to Rainy Mountain is a dynamic combination of language and structure: a provocative dialogue-or triologue to be exact-that invites questions without threatening "nonliterary" students. There is enough of a straightforward narrative (beginning with origin myths and early history and proceeding through the nineteenth and twentieth centuries) to convince students that they know what's going on. But the organization of the book is so unusual that students are forced to wonder what's really going on. The body of the book is divided into three major sections-"The Setting Out," "The Going On," and "The Closing In"and subdivided into twenty-four chapters. Each chapter is composed of three voices set in different type styles: for most of the book a myth or legend appears on the left page; this is answered by a factual historical or anthropological observation and a personal memory or comment on the right page. (Unfortunately this format was changed in the Ballantine edition.) These twenty-four trios are framed by an opening poem, a prologue, an introduction and an epilogue, and a closing poem. As in Hemingway's In Our Time, the combination of chronological narrative and an unusual fragmented structure offers both a comfortable and a challenging reading experience.

And this reading experience encourages students to question some of their most basic assumptions about Indians. The complexity of the structure convinces them that Indians aren't kid stuff, and the variety of the subject matter (sometimes beautiful, sometimes commonplace, cruel, or ugly) and the diversity of viewpoints make classifying Indians as one-dimensional saints or savages seem ridiculous. The most important challenge of The Way to Rainy Mountain, however, is that it encourages non-Indian readers to perceive reality in new ways, and this discovery undermines the vanishing-relic-of-dead-cultures stereotype.

Again, as with the ironic use of the Plains Warrior image, Momaday achieves this by first seducing the reader with the familiar only to shock him with the unfamiliar. The initial chronological narrative and the divisions between spiritual (myth), objective (historical and anthropological facts), and subjective (memories) reality conform to the conventional linear concept of time and the rigid categorization of different types of reality that form the basic frames of reference for the white, American (possibly Western civilization's) world view. But as students discover the gradual merging of the three voices near the conclusion and the links between the voices throughout, they begin to realize how inappropriate their

\footnotetext{
${ }^{2}$ Kenneth Fields, "More Than Language Means," Soutbern Review, NS 6 (Winter, 1970), 199, 197.
} 
concepts of time and reality are when confronted with the types of experiences presented by Momaday. Hence they are encouraged to experiment with dynamic interminglings of the past and the present, the cultural and the personal and the spiritual, objective, and subjective if they are going to understand what Momaday means by the "miracle" of the Kiowa culture: the collapse of that culture and the persistence, wholeness, and vitality of the same culture, which is renewed each time the imagination recreates ancient and recent pasts to illuminate presents and futures.

Though flattering, these generalities do little justice to the vitality of Momaday's prose poem. The Way to Rainy Mountain "must be seen to be believed. There is no substitute for the two hours necessary to read it." ${ }^{3}$ Still, one poor substitute is to briefly analyze several chapters. Almost any chapter could be used to demonstrate the brilliance and economy of Momaday's style, but the following three (IV, XIX, XXIV) taken together help to illustrate how Momaday comments on old and new stereotypes, how he achieves the diversity that makes the book an exciting anthology, and how he acquaints non-Indians with Kiowa concepts of time and reality. ${ }^{4}$

Chapter IV begins with a condensed version of a Kiowa legend. A beautiful child is placed in a magical tree and is visited by a strange red bird. As she climbs after the bird, the tree begins to grow taller and the child is "borne up into the sky." She turns into a woman; the bird becomes the sun, and he takes her for his wife. This legend is answered by a three-sentence glimpse of the Southwest "where the land itself ascends into the sky." The third voice offers personal memories of mountain meadow walks: recollections of "Indian paintbrush, lupine, and wild buckwheat"; a lodgepole pine and the male pine grosbeak; images of branches that "seemed very slowly to ride across the blue sky."

Each voice makes its own contribution, but it is the trio that makes the most profound statement. When a non-Indian student reads the myth, he or she tends to classify it as a girl-in-the-tree equivalent to a jack-in-the-beanstalk tale-a delightful story with little relation to reality. But the factual and personal accounts force the student to see that the myth is firmly grounded in several realities: a real landscape, a real bird, and a real visual effect (viewing the branches of an isolated southwestern pine against a southwestern sky). This discovery encourages a reevaluation of conventional non-Indian divisions of reality and illuminates one of Momaday's primary themes: "the revelation of one way in which these traditions are conceived, developed, and interfused in the human mind" (p. 4).

Chapter XIX also suggests the relationships between a cultural heritage and individual perceptions. It opens with a legend about a Kiowa who rescues his captured brother from the Utes. The Ute chief proclaims that if the Kiowa can "carry his brother on his back and walk upon a row of greased buffalo heads without falling to the ground, both brothers [will] be given horses and allowed to return to their home." He accomplishes the feat and the Ute is true to his word. Next Momaday presents the aftermath of the "fight at Palo Duro

\footnotetext{
${ }^{3}$ Fields, p. 200.

4 All quotes are taken from, and page references are to, the first edition published by the University of New Mexico Press in 1969.
} 
Canyon." "Nearly 800 horses were killed outright; two thousand more were sold, stolen, given away." Later the Kiowa were forced to kill and eat "their ponies ... to save themselves from starving."

The legend suggests key elements in the Plains Warrior image. It offers an analogy for a central function of horses (beasts of burden) and expresses qualities such as loyalty, respect for bravery, agility, and truthfulness that have long been associated with the Plains Warrior and Patriot Chief stereotypes. After this familiar image, Momaday shocks the reader with the sudden and brutal reality of the collapse of the golden era of the Kiowa horseman. The juxtaposition also underlines how differently Indians and whites could treat their enemies, the humiliating cruelty of the conquest of the Indians, and the unwillingness of whites to acknowledge Indian values-the contrast between the exciting legend and the matterof-fact horse statistics makes this clear.

Considering the clashes between these two voices, it is not surprising that many reviewers and critics have commented upon the "nostalgic" tone of the book and its ability to "nag eloquently at the white conscience." ${ }_{5}$ This is not the whole story, however. As in most other chapters, the third voice in Chapter XIX makes simplistic labels such as "nostalgic" and "white conscience" almost irrelevant. The persona's recollections of his own horse implies unflinching observations about the past and the present. The glorious era of the Kiowa is dead and gone. There are no amazing escapes or mythic steeds and buffalo in the landscape; just a kid on a red roan. And yet that child's geographical, cultural, and family heritage allowed him to "know" horses as a vital, total experience: a concrete, sensual feeling that captures the touch and the sound of riding and a mystical brotherhood with the land and the seasons.

Chapter XXIV, the last chapter before the Epilogue, again confronts the paradox of the vitality of a "dead" culture. In the first paragraph the persona recalls the dress of a beautiful woman buried "East of my grandmother's house": "It was one of those fine buckskin dresses, and it was decorated with elk's teeth and beadwork. That dress is still there, under the ground." A detailed description of his grandmother's moccasins answers this memory. Finally, the landscape "East of my grandmother's house" reminds the persona that

Once in his life a man ought to concentrate his mind upon the remembered earth, I believe. He ought to give himself up to a particular landscape in his experience, to look at it from as many angles as he can, to wonder about it, to dwell upon it. (p.83)

By Chapter XXIV the divisions between myth, historical fact, and personal reflection have all but disappeared suggesting a dynamic literary structure moving towards complexity and the familiar historical phenomenon of an intimate but blurred, conglomerate present as contrasted to a more arbitrary, selective, and categorized view of the past. This chapter also suggests a private sense of vitality and resolution. In the Preface and Introduction, Momaday noted the importance of the sacred Tai-me to the Kiowa. While describing the journeys of the Kiowa

5See Fields, p. 203; Wayne Gard, "Southwest Chronicle," Soutbwest Review, 54 (Summer, 1969), vii; "Briefly Noted," New Yorker, 17 May 1969, p. 152; Phoebe Adams, "Short Reviews: Books," Atlantic Montbly, 223 (June, 1969), 117. 
and his pilgrimage to his grandmother's grave, he also recorded an instance of the fusion of cultural and personal memories. Though his grandmother had not traveled with her ancestors from the mouth of the Yellowstone River, "She could tell of the Crows, whom she had never seen, and of the Black Hills, where she had never been." Momaday hoped that one day he too would be able to "see what she had seen more perfectly in the mind's eye" (p. 7). Now, near the conclusion of Momaday's pilgrimage, he has found an object that is as sacred to him as the Tai-me was to his ancestors-Aho's moccasins-, and he too can "see more perfectly" with the "mind's eye" (imagination) what he never saw-the beautiful dress buried east of Aho's house.

Considering the beauty and power of Chapters IV, XIX, and XXIV and the rest of The Way to Rainy Mountain, and its practical advantages as an introduction to the inadequacies of Indian stereotypes, the diversity of Indian literature and experience, and some rather unAmerican Native American views of time and reality, it is not surprising that the book has received favorable comment. ${ }^{6}$ Nevertheless, The Way to Rainy Mountain is still relatively unknown, existing in the shadow of its famous brother, House Made of Dawn, and suffering from a restrictive "Sociology/Anthropology" label bestowed by Ballantine Books. (Moby-Dick would come under "Maritime/Industrial History" by these standards.) "Practical/ Poetic/Powerful" would be more appropriate, especially for the many unfortunate instructors "caught between the two worlds" of the survey course and the richness and diversity of American literature.

${ }^{6}$ For reviews and articles see Martha Scott Trimble, N. Scott Momaday (Boise: Boise State College Western Writers Series, 1973), pp. 44-45. See also "Teaching Indianness," pp. 7-10.

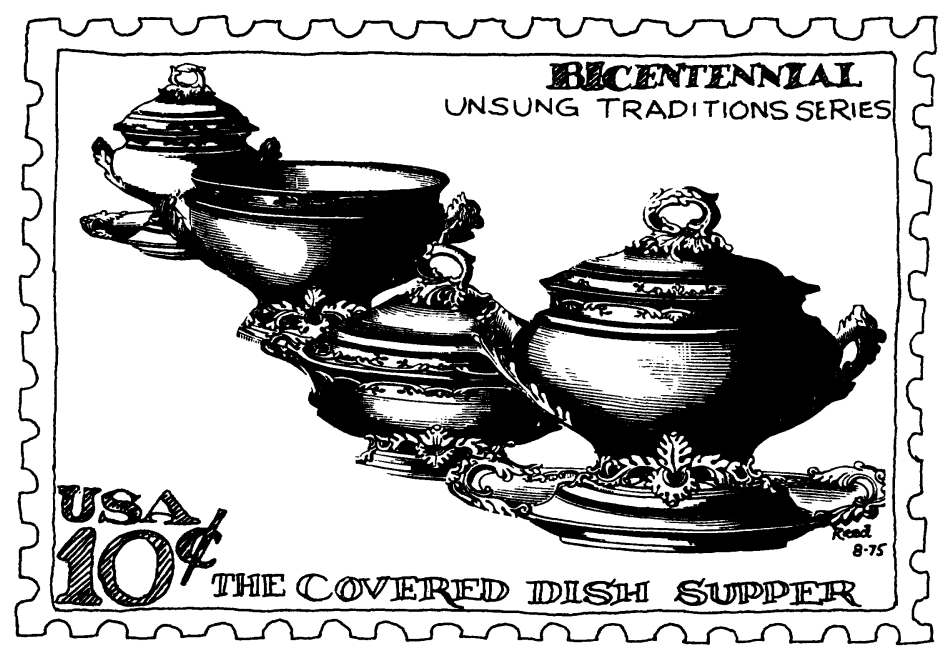

ORIGIN OF SPECIOUS

Truth in a beagle?

Swans sing and then die.

Nay, horse laughs are stable, but sleeping dogs lie.

Steven G. Kellman 